\title{
ENGLISH READING AND WRITING PERFORMANCE OF XITSONGA-SPEAKING GRADE 7 LEARNERS IN TOWNSHIP SCHOOLS: A CASE STUDY
}

\author{
TV Manyike \& EM Lemmer \\ University of South Africa
}

A clear preference for English as language of teaching and learning (LoLT) is evident in most South African schools. However, discrepancies exist between language policy aims and educational outcomes with regard to the successful acquisition of English among English second language (ESL) learners. Effective participation in all learning activities is closely linked to learners' proficiency in the LoLT; poor English proficiency leads to underachievement across the curriculum. In the light of this, a case study as conducted to investigate the English reading and writing performance of Grade 7 Xitsonga-speaking learners in three selected township schools in the Tshwane metropolitan area, Gauteng Province. Firstly, a literature review was undertaken to explore the importance of reading and writing skills in the classroom with particular reference to the demands made on ESL learners. Following this, standardised tests were used to assess the learners' English reading and writing performance. Findings indicated that learners performed poorly in both reading and writing; however, no significant relationship could be demonstrated between reading and writing, possibly due to the nature of the components of the test. The overall lack of reading and writing competence in English holds implications for learners' academic achievement in all learning areas in situations in which English is used as the LoLT.

\section{Key words}

Reading performance; Writing performance; Grade 7 L2 learners; English Second language; Standardised testing

\section{INTRODUCTION}

A primary challenge in South African schools in which stakeholders have opted for English as language of learning and teaching (LoLT) is to meet the needs of learners from linguistically diverse backgrounds who display limited English proficiency. Although less than ten percent of the population of South Africa are native English speakers, English has obtained dominant status particularly as the language of higher education, commerce and government (Republic of South Africa [RSA] 2008). A clear preference for English as language of teaching and learning (LoLT) has also emerged in most South African schools in post-apartheid South Africa (Alexander, 2005:120). A number of factors have contributed to this trend. The preference for English as LoLT is the result of strong pragmatic incentives resulting from of the socioeconomic mobility associated with English and its traditional place in the workplace in general and commerce in particular. English has come to be considered the most likely and acceptable lingua franca which can contribute to the process of nation-building in a historically divided 
nation and its role as functional linking language in the new government appears assured (Pastowsky, 2008). However, Alexander (2002:125) contests the assumption that a preference for a dominant language, in this case, English, is merely the result of the mentioned 'common sense' assumptions about a language and its socio-economic usefulness in society and in a globalising world. He argues that the current privileging of English and its concomitant association with social, economic and political power in South Africa promotes linguistic elitism and has been accompanied by a loss of linguistic capital among speakers of African languages and the disempowerment of these languages. Although the African languages may be maintained in the primary contexts of family, community and religious practice, access to English through schooling is seen as a major priority among most black South Africans, who still link mothertongue-based education with the inequities of 'Bantu education' of the apartheid era (Alexander, 2002).

Vast discrepancies between parental choice of LoLT, language policy intentions and educational outcomes exist with regard to the successful acquisition of English among South African learners. Learners' meaningful participation in school learning activities is closely linked to their proficiency in the LoLT; those who lack adequate levels of proficiency usually achieve poorly (Brock-Utne \& Holmarsdottir, 2004:67). According to Heugh (2000:42), most South African learners never achieve the required level of competency in English to achieve in different learning areas of the curriculum and this fact is a major contributor to poor matriculation results. Most South African schools adopt a sudden transfer to English, usually after four years of schooling (Pretorius \& Mampuru, 2007:40). This is an adaptation of assimilationist English Second Language (ESL) methodologies, which are common practice in Britain and the United States. A fundamental principle of such an assimilationist approach is to prepare speakers of languages other than English to learn through English and to exist in a dominant English-speaking environment (Heugh, 1995:45). The implication of this approach in the South African classroom is that learners have to acquire English proficiency while already using English as LoLT in all learning areas and to the detriment of mother tongue development. Learners must master the concepts typical of a particular learning area and face other discipline-related demands made on language skills, such as the linguistic knowledge, conceptual knowledge and procedural knowledge related to a content area in the second language (L2) (Virginian Department of Education, 2006). This constitutes a formidable challenge for the ESL learner in the South African classroom where poor environmental contexts, poor resources, overlarge classes, inadequate textbook supply, weak management infrastructure, teachers with limited English proficiency and the general demoralisation in the teaching corps exacerbate the problem of effective English language learning (HSRC, 2004:80; MacDonald, 2006:59).

Against this background, it is not surprising that international surveys of English literacy in which South African learners have taken part paint a dismal picture. According to the Southern African Consortium for Monitoring in Educational Quality (SACMEQ) 11 Project, which monitored educational achievement across fifteen Southern and Eastern African countries in 2002, only $36,7 \%$ of South African learners reached minimum levels of mastery in reading at Grade 6 level. Less than $10 \%$ of learners reached minimum levels with regard to interpretive reading, inferential reading, and critical reading skills; just over $10 \%$ of learners met the minimum level for analytical reading ((Moloi \& Strauss, 2005). The Progress in the International Reading Literacy Study (PIRLS), which aims at providing internationally comparative data of reading assessment, indicated that Grade $4 \mathrm{~s}$ and $5 \mathrm{~s}$ in South Africa came last in a study of forty countries in 2006 (International Association for the Evaluation of Educational Achievement, 2006). As reading and writing skills are interdependent and 
literacy development is dependent on this interconnection, it can be expected that the writing performance of South African learners in academic contexts is similarly weak.

Against the background of this discussion, a case study was undertaken to examine the reading and the writing performance in English of Xitsonga Grade 7 learners in three selected schools in the Tshwane metropolitan area, Gauteng, which have opted for English as the LoLT from Grade 4 onwards. The paper begins with a discussion of the importance of reading and writing skills in the classroom, with particular reference to the demands of the L2 context. This is followed by the research design and results of the case study in which data were gathered using standardised language performance testing. Finally, a discussion of the findings is presented and recommendations are made for future practice.

\section{READING AND WRITING AND THEIR ROLE IN ACADEMIC ACHIEVEMENT}

Traditionally, reading and writing have been taught separately in schools. Although the two language skills are usually taught by the same teacher during the school periods devoted to language, teachers rarely make explicit connections between the two (Pressley, Mohan, Raphael \& Finegret, 2007:223). However, reading and writing are interdependent skills and effective literacy development is dependent on this interconnection (Campbell, 1995:43; Krashen, 1990:67). Children who read more develop better writing skills (Krashen, 1990: 68); similarly, children learn to read by writing (Crandall, 1994). In the primary school young children spend much time reading stories, which provide an excellent resource for helping them to develop literacy skills and provide language input for their own expressive writing (McClellan \& Fields, 2004:50). According to Martin and Leather (1994), engagement with children's literature helps children learn about language and how various texts work. However, there is some overemphasis on fictional texts in the foundation and intermediate phases of schooling. As children move into senior primary phase and into secondary school, their reading and writing become increasingly subject-related and thus more complex. Where language classes primarily use literary texts, learning in other subjects requires the use of factual texts. Each genre calls for particular reading and writing skills (Hyland, 2007:148). If children have had little experience with factual texts before reaching secondary school, they may experience difficulty in reading and writing factual texts. Moreover, teachers often assume that reading and writing skills are taught through the reading and writing of fictional texts in the language class and that these skills are transferred automatically to all other content areas and require little further attention by content area teachers (Hall, 2005:403). This is questionable for the following reason. Various subjects require specific genres of writing or combinations of these genres which have particular characteristics with accompanying demands being made on the young writers and on teachers who need to supply them with specific strategies in this regard (Pawan, 2008:1452; Harklau, 2002:329). In early schooling, different domains of knowledge overlap, but by the time children reach senior primary, knowledge is organised in distinct fields.

A major aim of schooling is to develop explicit, disciplined and increasingly abstract understanding of these fields of knowledge. Each academic discipline explores the world in a different way and these different perspectives are reflected in the terminology of the discipline (Schleppegrell \& De Oliviera, 2006:254). To deal with this, cognitive academic language proficiency (CALP), the highly ordered and specific language of school knowledge, is essential; without it the learner will not succeed (Daniels, Zemelman \& Steineke, 2007). By illustration, in an Australian study, teachers found that the reading comprehension of 
secondary school learners had not developed beyond one or two basic kinds of texts, in which the language which was used was similar to that used in everyday spoken interactions. Also, the examples of writing typically produced by these learners were not the kinds of texts which would support achievement in the subject areas as learners progressed through school (New South Wales Department of Education and Training, 1999). Further, many teachers assume that CALP is acquired automatically. But familiarity with literature and an ability to write creatively and expressively do not guarantee that learners will master the language of the content areas and the requirements for reading and writing across the curriculum (Crandall, 1994:256). The language of content areas should be identified and explicitly introduced to learners to ensure that they are not disadvantaged by leaving such knowledge to chance. For these reasons, every teacher in each learning area should teach the reading and writing skills needed within the framework of the subject discipline for which he/she is responsible (Kaufmann \& Crandall, 2005). Yet, according to Rodseth (1995:216), CALP is neglected in cross-curricular reading and writing in South African schools. Conversely, where content teachers do accept their role as academic reading and writing teachers and provide students with explicit, demanding instruction connected to content learning, students are enabled to produce high reading and writing achievement (Pressley, Mohan, Raphael \& Finegret, 2007:221).

\section{Reading and writing in the $\mathbf{L} 2$ classroom}

The complexity of reading and writing performance and their role in academic achievement are compounded in the L2 classroom (Crandall, 1994). Although reading and writing in L1 share many similarities with L2 reading and writing, differences in L1 and L2 discourses have been identified. Retelling and comprehension appears to be partly determined by different types of text structure and certain language groups comprehend and recall certain types of text better than others (Kang, 1992:93). Early work on the effect of contrastive rhetoric by Kaplan (1966) showed that L1 dimensions of discourse and text structure also create challenges in L2 writing. Once a person learns a certain way of writing in one language, this schema influences writing in L2. To illustrate this problem, Connor (1996) found differences in the essay writing of Asian students in comparison with American students instructed in a different essay tradition. Uysai (2007:183) found similar results among the essays written in Turkish and English by Turkish-speaking students. Thus, teachers in multilingual classrooms should be aware of culturally shaped expectations of text and their effect on reading comprehension and writing.

Furthermore, L2 learners may experience intense problems in content area learning because they have not yet acquired the CALP needed to succeed in understanding the subject matter content. Because the language of academic subjects requires a high degree of reading and writing ability that young L2 learners may not have developed yet, they may experience difficulties reading their textbooks and understanding the vocabulary unique to particular school subjects (Christian, Spanos, Crandall, Simich-Dudgeon \& Willets, 1995:216). This finding has been repeated in the South African context (MacDonald, 1990; 2006). According to Collier (1995), L2 student's progress from acquiring basic interpersonal communication skills (BICS) to the more complex academic language with increased exposure to English, but this takes a minimum of seven to ten years if all schooling takes place in L2. Only then is the student able to argue and defend academic points of view, read textbooks suitable to the grade level and write organised and fluent essays. This correlates with the advanced fluency stage of Krashen's (1982) model of language acquisition. The latter lists five stages of second language acquisition; preproduction (minimal comprehension); early production (limited 
comprehension); speech emergence (increased comprehension); intermediate fluency (good comprehension); and advanced fluency, the final stage in which the student has reached a near-native level of speech and has developed academic language proficiency. For the purpose of this study it is relevant to note that intermediate fluency takes the L2 learner three to five years to reach; advanced fluency takes the L2 learner five to seven years to reach.

\section{METHOD}

In the light of the above discussion, a case study using standardised testing was undertaken to investigate Grade 7 Xitsonga-speaking learners' English reading performance and their English writing performance in three selected primary schools in the Tshwane metropolitan area, Gauteng Province.

\section{The sample}

Three primary schools situated in two townships in the Tshwane metropolitan area were chosen by purposive sampling. Stake $(2005: 450)$ points out that the greatest understanding of a phenomenon rests with careful choice of the case. Purposive sampling is used to select information rich cases for an in-depth study, specifically, when the researcher wants to understand the phenomena without needing to generalise the results. In this case, the researcher looked for township schools which had been classified as Xitsonga medium schools by the Gauteng Department of Education and would present a relatively homogeneous linguistic community in that learners at these schools identified Xitsonga as their mother tongue. In all three schools, Xitsonga is used as the LoLT from Grade R to Grade 3 and English is gradually introduced as an additional language. In Grade 4, however, learners transfer to English as LoLT; Xitsonga is taught as an additional language and English is taken as the primary language. Observation carried out in the schools indicated that two schools had libraries but these were infrequently used by teachers and learners. Teachers of Grade 4 were adequately qualified; however, only two were L1 Xitsonga speakers.

All Grade 7 learners $(\mathrm{n}=162)$ attending the three schools were selected to form a comprehensive sample. Two classes of Grade 7 learners in School 1 and one Grade 7 class in each of the other two schools (i.e. Schools 2 and 3) participated. In all schools most learners came from poor socio-economic conditions, with a large component coming from nearby informal settlements. All learners were L1 Xitsonga speakers who had been using English as LoLT since Grade 4. If optimal language learning conditions prevailed in the classrooms, the learners would have had three years intensive and sustained exposure to English.

\section{Data gathering and data analysis}

Data were gathered by means of two tests, namely: the Reading Performance Test and the Writing Performance Test in English (Intermediate Level) as developed by the Human Sciences Research Council (HSRC). These are standardised tests aimed at determining reading and writing performances in the Intermediate Phase. The particular tests are applicable to L1 and L2 speakers, although different norms apply to these groups. These tests are the only standardised language tests available for this purpose at present. To write the Reading Performance Test, a candidate is supplied with a test booklet, an answer sheet, a pencil and an eraser. This Reading Performance Test is composed of multiple choice questions and learners are expected to choose the correct answers. In the Writing Performance 
test, a candidate is supplied with a test booklet, a pen, and blank folio paper for planning answers.

The Reading Performance Test in English has two components: comprehension and grammar. The contents and structure of the test are summarised in Table 1 and Table 2.

Table 1: Component: Reading comprehension

\begin{tabular}{|l|l|l|}
\hline Skill being tested & Number of items tested & Question numbers \\
\hline $\begin{array}{l}\text { Recognising denotative } \\
\text { meaning of words }\end{array}$ & 1 & 26 \\
\hline $\begin{array}{l}\text { Understanding details of } \\
\text { content }\end{array}$ & 9 & $1 ; 3 ; 4 ; 5 ; 6 ; 8 ; 10 ; 15 ; 31$ \\
\hline $\begin{array}{l}\text { Making general inferences } \\
\text { based on the given text }\end{array}$ & 5 & $2 ; 7 ; 9 ; 11 ; 21 ; 22$ \\
\hline $\begin{array}{l}\text { Making inferences related } \\
\text { to the writer's intention }\end{array}$ & 1 & 17 \\
\hline $\begin{array}{l}\text { Making inferences related } \\
\text { to the main idea }\end{array}$ & 2 & $12 ; 14$ \\
\hline $\begin{array}{l}\text { Selecting precise words to } \\
\text { describe something in } \\
\text { context }\end{array}$ & 3 & $27 ; 28 ; 29$ \\
\hline
\end{tabular}

Source: Chamberlain \& Reinecke (1992:17)

Table 2: Component: Grammar

\begin{tabular}{|l|l|l|}
\hline Skills being tested & Number of items & Question numbers \\
\hline $\begin{array}{l}\text { Recognising correct } \\
\text { idiomatic use }\end{array}$ & 5 & $16 ; 18 ; 19 ; 20 ; 30$ \\
\hline $\begin{array}{l}\text { Selecting correct use of } \\
\text { parts of speech }\end{array}$ & 9 & $32-40$ \\
\hline $\begin{array}{l}\text { Making inferences related } \\
\text { to the atmosphere }\end{array}$ & 1 & 13 \\
\hline $\begin{array}{l}\text { Recognising expanded } \\
\text { meaning of summarised } \\
\text { text }\end{array}$ & 2 & $23 ; 25$ \\
\hline $\begin{array}{l}\text { Selecting appropriate } \\
\text { language for the situation }\end{array}$ & 1 & 24 \\
\hline
\end{tabular}

Source: Chamberlain \& Reinecke (1992:17)

The Writing Performance Test in English (Roux, 1997) requires four tasks: the written description of pictures; spelling; sentence completion; and a short structured essay. The contents and structure of the test are summarised in Table 3 and Table 4. 
Table 3: Component: Spelling and syntax

\begin{tabular}{|l|l|l|}
\hline Skills tested & Number of items tested & Question numbers \\
\hline $\begin{array}{l}\text { Denotative meaning of } \\
\text { words and spelling } \\
\text { (picture) }\end{array}$ & 12 & $1-4 ; 7-8 ; 11-16$ \\
\hline Syntax & 1 & 9 \\
\hline
\end{tabular}

Source: Bernard \& Reinecke (1992:19)

Table 4: Component: Sentence writing and creative writing

\begin{tabular}{|l|l|l|l|}
\hline Skills tested & $\begin{array}{l}\text { Number of items } \\
\text { tested }\end{array}$ & Question numbers & \\
\hline Sentence writing & 2 & $5 ; 6$ & \\
\hline Creative writing & 2 & $10 ; 17$ & \\
\hline & & & \\
\hline
\end{tabular}

Source: Bernard \& Reinecke (1992:19)

The test manual does not give any indication of what is considered a pass mark as performance depends on the context in which the test is written. However, $40 \%$ (or a raw score of 20 out of a possible total of 50) is given as a guideline for the Writing Performance Test; and 40\% is given as guideline for the Reading Performance (a raw score of 16 out of the possible score of 40). These guidelines were used in the inquiry and allowed for comparison of results. Furthermore, the Reading Performance and the Writing Performance tests had reliability coefficients of 0,89 (Chamberlain \& Reinecke, 1992:18) and 0,84 (Bernard \& Reinecke, 1992:21) respectively. For this kind of test, a reliability coefficient of 0,8 or higher can be regarded as satisfactory. Regarding test validity, the items of both tests were accepted by a committee of subject experts after a specification table had been drawn up and a thorough study had been made of the suitability of the items to test reading and writing performance (Bernard \& Reinecke, 1992:21). With regard to the issue of possible cultural bias, the tests dealt with topics of everyday occurrences at home and at school.

The total number of participants who wrote each test differed slightly due to absenteeism on the days on which the respective tests were taken. The tests were scored by the primary researcher and statistical procedures followed by an expert statistician were used to analyse the raw data.

\section{FINDINGS}

\section{The Reading Performance Test in English}

A total of 162 learners wrote the Reading Performance Test in English. The results are presented according to the scores for the comprehension component $(\mathrm{Q} 1-12,14 ; 15 ; 17 ; 21 ; 22$; $26-29 ; 31)$ and for the grammar component (Q 13; 16; 18-20; 23-25; 32-40). The comprehension component had a maximum possible score of 22 and the grammar component had a maximum possible score of 18 .

The bar chart in Figure 1 gives the tabulated results of the comprehension component. 
Figure 1: English comprehension

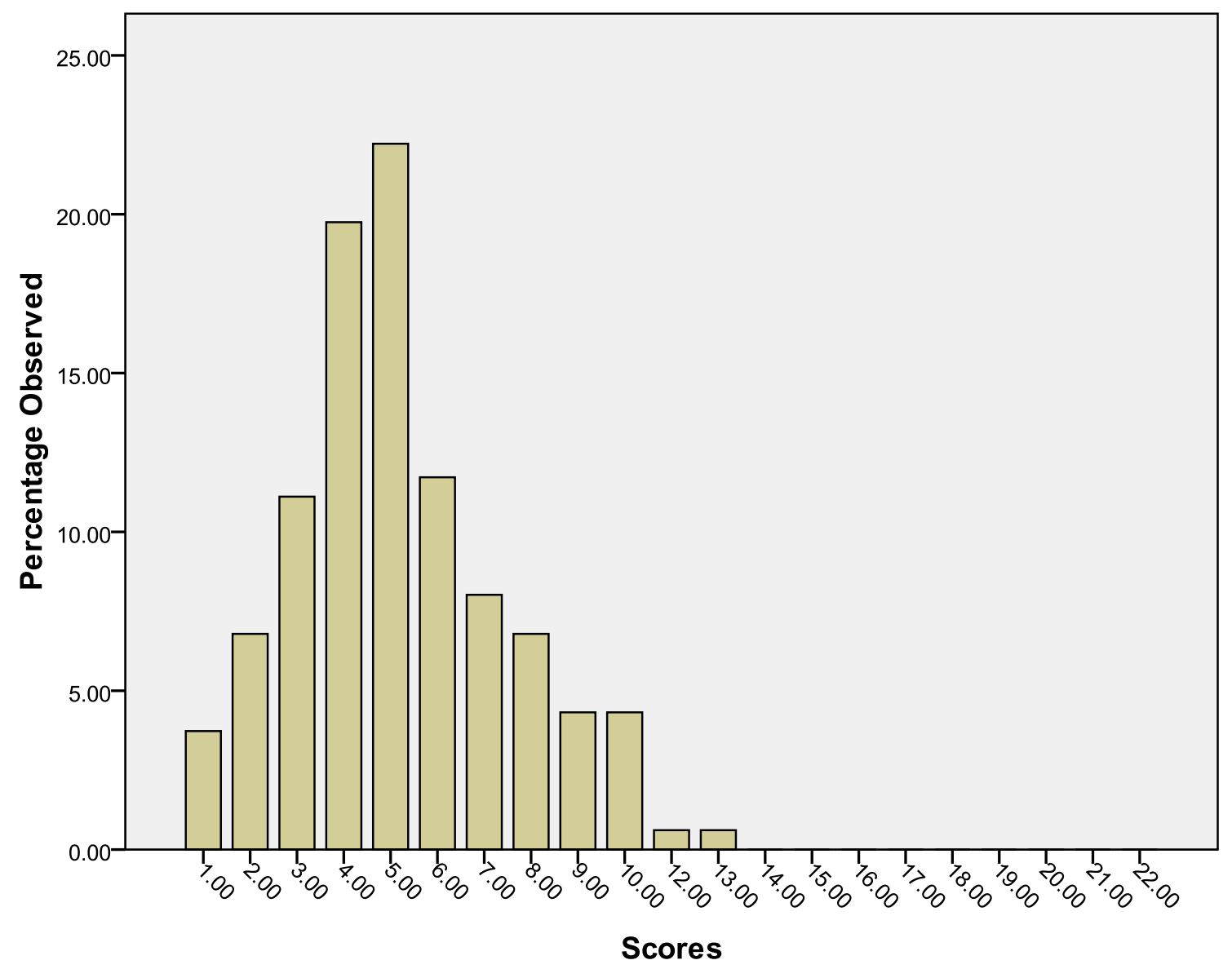

Figure 1 shows that the possible scores ranged from one to 22. The graph is almost normally distributed. Its slight skewness to the right shows that few learners performed well. Just over ninety per cent $(90.12 \%)$ of the learners scored below the $40 \%$ pass mark (which is equivalent to 9 out of maximum possible score of 22) and only $10 \%$ of the learners passed. The largest group of scores $(41.97 \%)$ were in the range of 4 to 5 , which indicates very poor performance. Overall, the mean score was 5.15, with a standard deviation of 2.31 . The mean score was less than $25 \%$ of the possible score, far below the mean score of 12 . These data show very poor performance in reading comprehension.

The bar chart in Figure 2 gives the tabulated results of the grammar component. 


\section{Figure 2: English grammar}

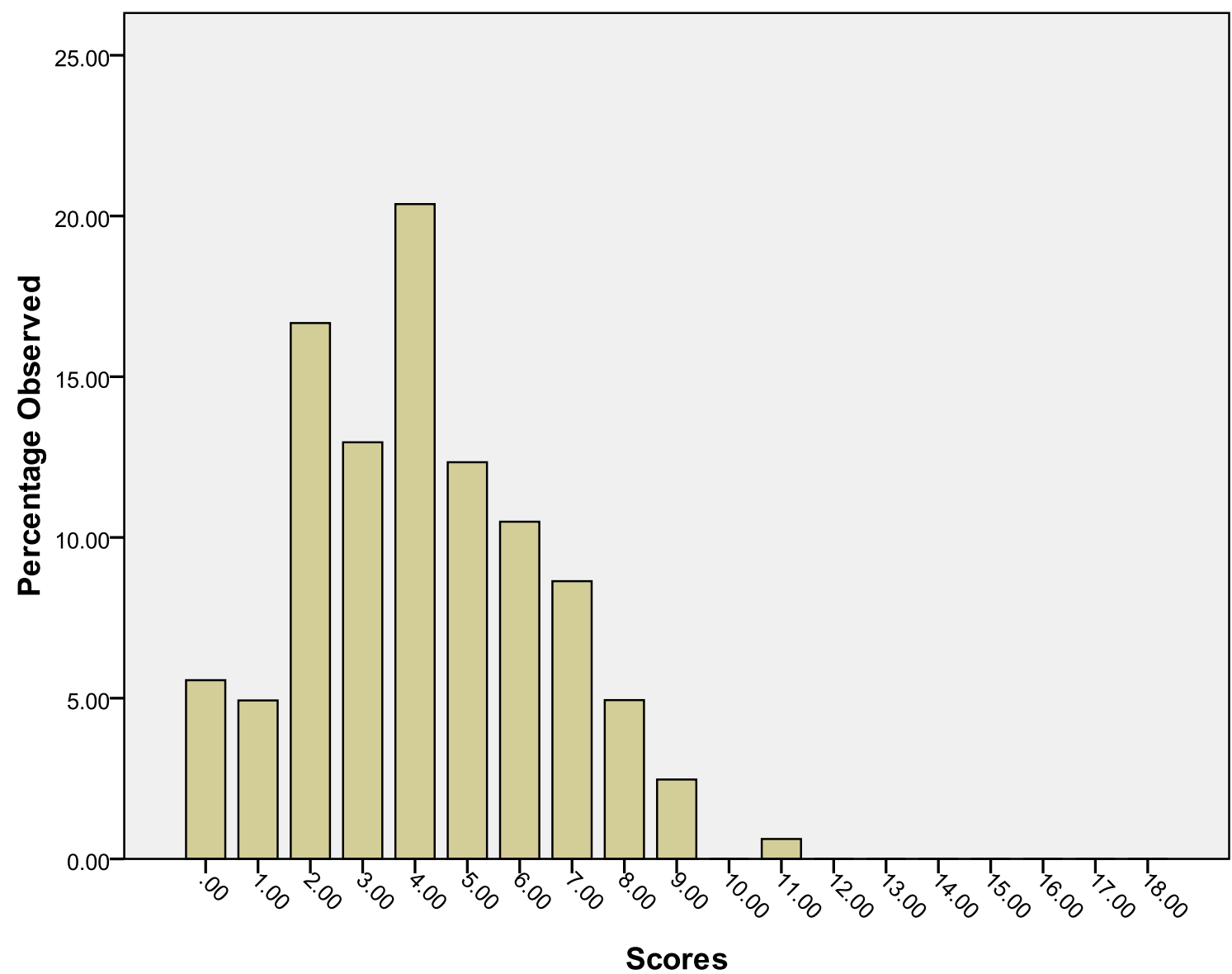

Figure 2 shows that the possible scores ranged from zero to 18 . The graph is slightly skewed to the right, which indicates that few learners obtained high marks. Just over eighty-three percent $(83.33 \%)$ of the learners scored below the $40 \%$ pass mark (which is equivalent to 7 out of a possible maximum score of 18) and only $16.67 \%$ of the learners passed. The majority of the scores (i.e., 81.47\%) ranged from 2 to 7 , which indicates poor performance. An additional $5.56 \%$ of learners obtained a zero score. The mean score was 4.13 , with a standard deviation of 2.31, with the highest score obtained being 11 out of 18 . The shapes of the two graphs are almost the same. However, the results for English grammar showed a larger variability of marks than English comprehension: a coefficient of variation of $55.9 \%$ compared to the comprehension coefficient of variation of $44.8 \%$. Thus, performance in comprehension was more consistent when compared to performance in grammar.

The results of the two components, comprehension and grammar (Figures 1 and 2), were combined to provide the overall results of the Reading Performance Test in English, which is as portrayed in Figure 3. 
Figure 3: Results of the Reading Performance Test in English

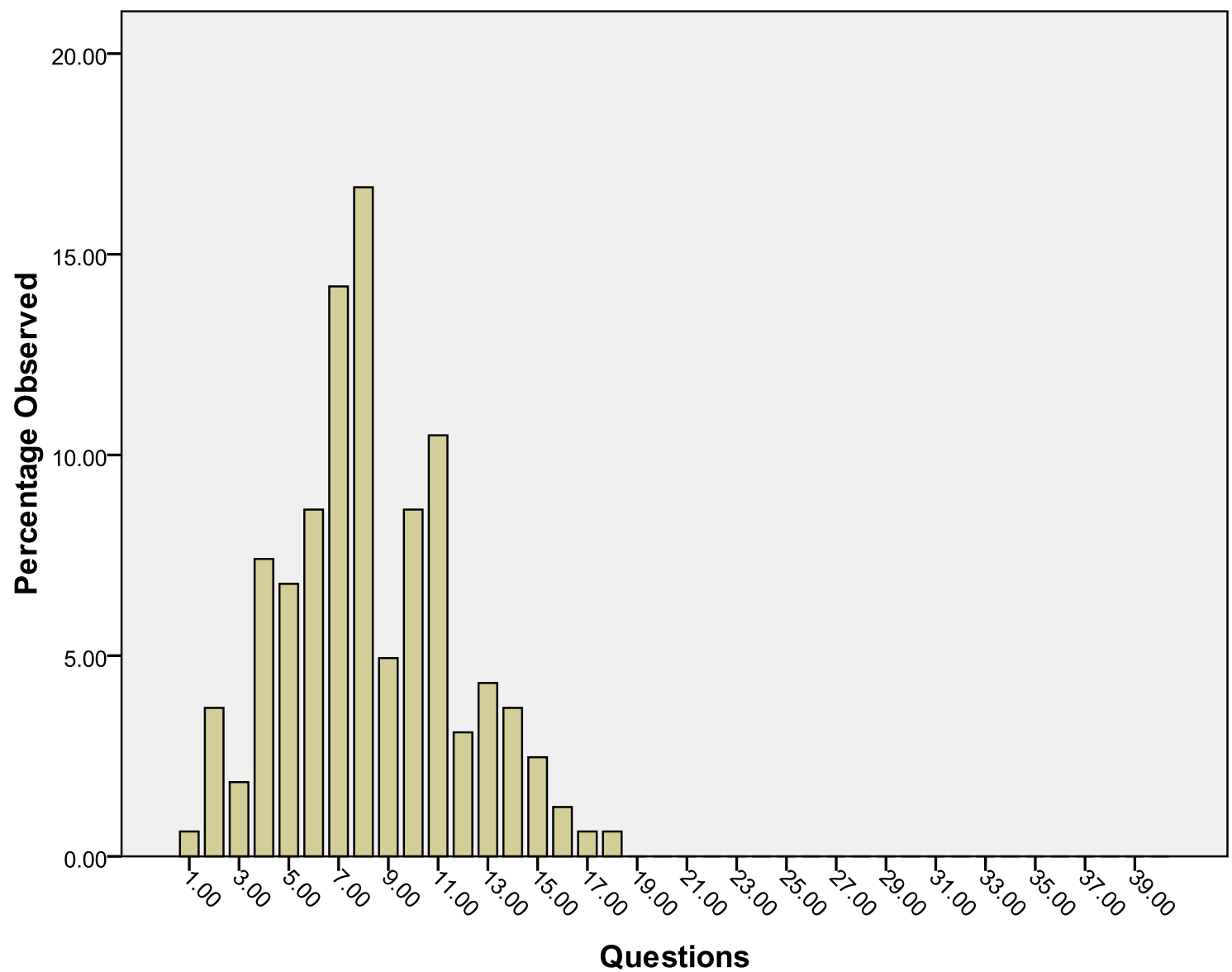

Figure 3 shows that the scores were almost normally distributed across the possible raw score range of from 1 to 40 . Learners who performed below the $40 \%$ pass mark (equivalent to 16 out of the maximum possible score of 40 ) made up $95,06 \%$ of the sample, thus $4.94 \%$ of the learners passed. Most of the learners obtained marks between 6 and $9(46,3 \%)$.

The combined mean score for the Reading Performance Test in English was 9.31 (standard deviation $=3.2$ ). The highest score obtained for Reading Performance was 19, with no learner obtaining zero. None of the learners obtained a score higher than 19 out of the possible score of 40 . The learners who scored below the $40 \%$ pass mark (equivalent to 16 out of the possible maximum score of 40) made up $95.06 \%$ of the sample and thus $4.94 \%$ of the learners passed. The top 4.94 percent of the raw scores fell between the 32 and 44 percentile ranks (equivalent to a stanine of 4 to 5, which indicates a low to average score). The majority of the scores range from 5 to 12 (equivalent to a stanine of 1 and 2, which indicates very poor to poor scores). The very poor stanine score of 1 was observed in 13.58 percent of learners.

The graph also shows the same positive skewness. The coefficient of variation is $34 \%$. This shows more consistency than the results of grammar and of comprehension separated. 


\section{The Writing Performance Test in English}

A total of 160 learners wrote the Writing Performance Test in English and two learners were absent on the day on which the test was written. The results are presented according to the scores in spelling and syntax (Q1-4; 7-9; 11-16) and sentence writing and creative writing (Q5, 6, 10 and 17). The spelling and syntax had a maximum possible score of 37 and sentence writing and creative writing had a maximum possible score of 13 .

The bar chart in Figure 4 gives the tabulated results of the spelling and syntax component.

Figure 4: English spelling and syntax

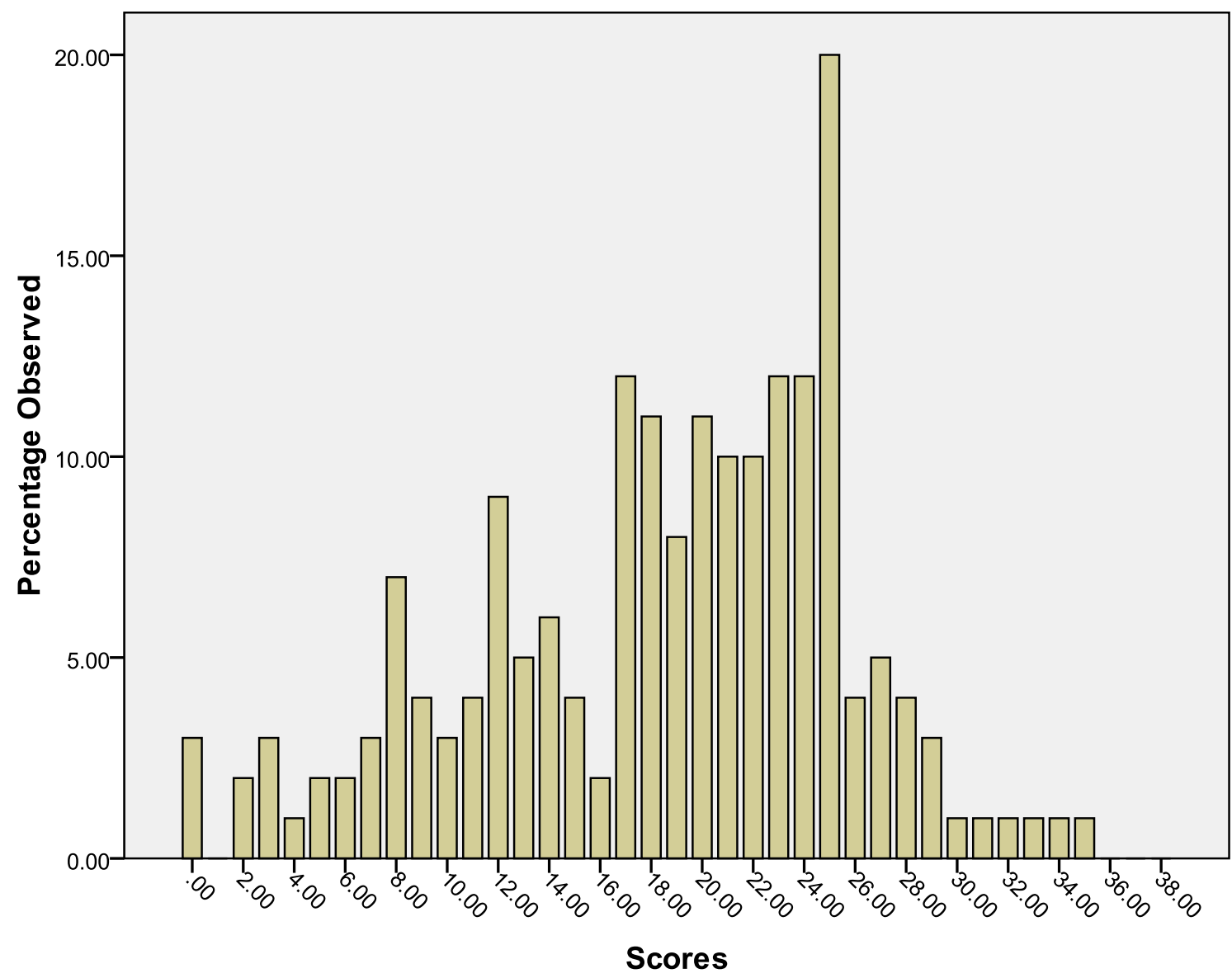

Figure 4 shows that the scores were almost normally distributed across the possible raw score range, which is from 0 to 37 , although there is some slightly positive skewness. Very few learners obtained marks between the raw scores 29 and 37 (5\% were between 29 and 36). Almost $31.18 \%$ of the learners performed below the $40 \%$ pass mark (getting a mark of 15 and above out of 40 ) and thus $68.82 \%$ passed. Thus the learners' performance in spelling and syntax was average. Most of the learners obtained marks between 17 and 26 (38.17\%). Overall, the mean was 17.69 , with a standard deviation of 7.59 , thus giving a coefficient of variation of $42.9 \%$. The mean score of 17.69 gives a mark of $47.8 \%$, which further supports the moderate performance of the learners.

This implies that learners performed reasonably better in the writing component: spelling and syntax, compared to the writing component: sentence writing and creative writing, with a 
mean score of 17.69 (standard deviation $=7.59$ ) and a highest score obtained being 35 . However, $0.61 \%$ of learners obtained a zero score.

The bar chart in Figure 5 gives the tabulated results of sentence writing and creative writing.

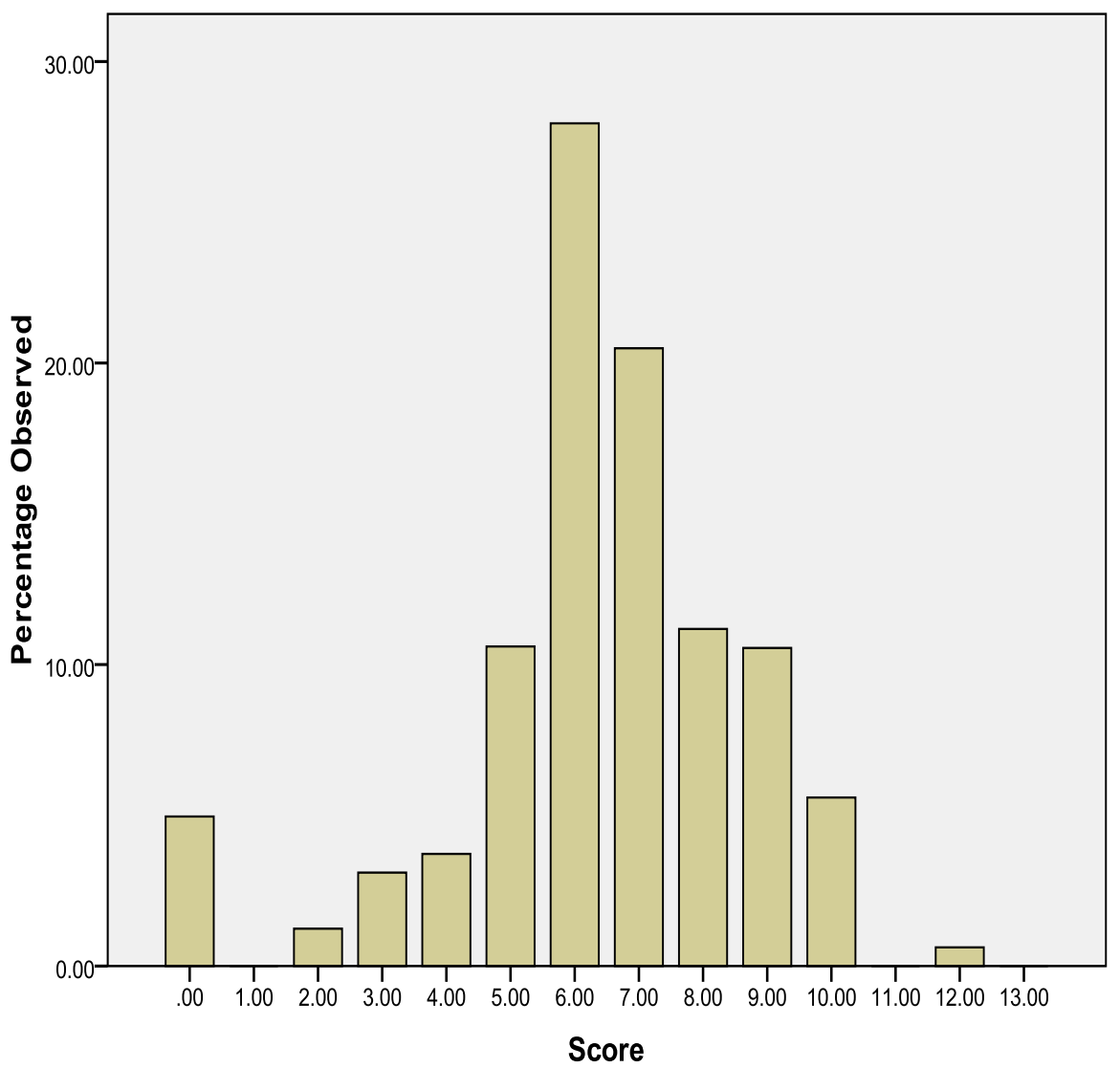

\section{Figure 5: English sentence writing and creative writing}

Figure 5 shows the learners' scores as almost evenly distributed from zero through 13 across the possible score. Most learners obtained marks between 6 and 7 with only a few attaining low or high marks. About $4.3 \%$ of the learners obtained zero score. Altogether $11.29 \%$ of the learners scored below the $40 \%$ pass mark (which is equivalent to 5 out of a possible maximum score of 13 ) and $88.71 \%$ of the learners passed. Altogether $49 \%$ of the scores were above $50 \%$. Overall, the mean score was 6.37 and the standard deviation was 2.27 , giving a coefficient of variation of $35.6 \%$. The marks for sentence writing and creative writing showed less variability (lower coefficient of variation) as compared to those for spelling and syntax.

The results of the two components: spelling and syntax and sentence writing and creative writing (Figures 4 and 5) were combined to give the overall results of the English Writing Performance test, as shown in Figure 6. 
Figure 6: Results of the Writing Performance Test in English

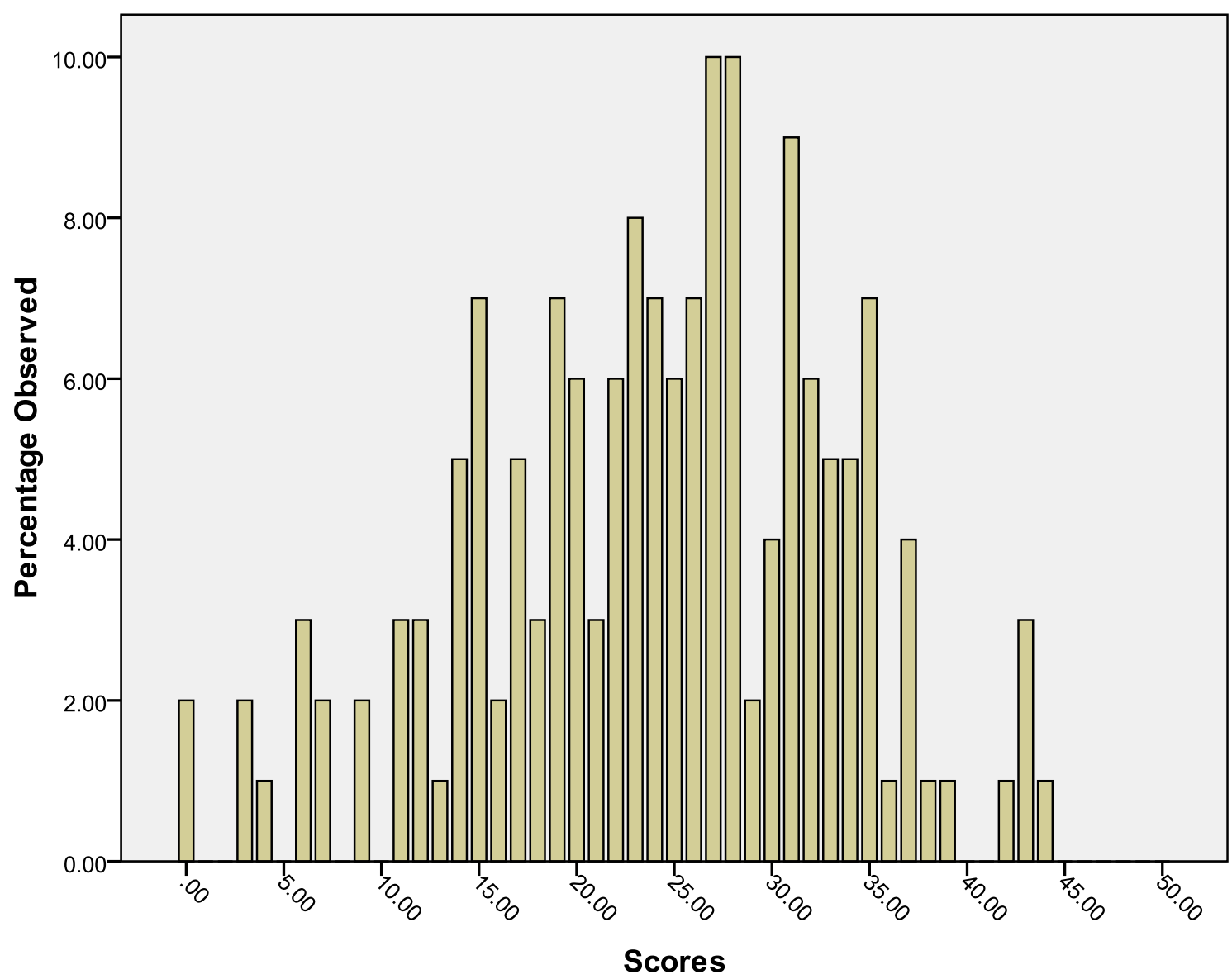

Figure 6 shows that the scores were almost normally distributed across the possible raw score range of from 0 to 50 . Learners who performed below the $40 \%$ pass mark (equivalent to 19 out of the maximum possible score of 50), made up $29.81 \%$ of the sample and thus 70.19 percentage of the learners passed. Most of the learners obtained marks between 22 and 28 $(29.81 \%)$.

The combined mean score for the Writing Performance Test in English (spelling and syntax and sentence and creative writing) was $24.06 \%$. Thirty-three point five four percent $(33.54 \%)$ of learners failed to obtain more than the suggested sub-minimum (raw score 20) for the Writing Performance Test in English. This means that two-thirds $(66.46 \%)$ of the learners were competent in writing skills in English. The highest score obtained for English writing was 44 out of the possible maximum score of 50 .

\section{A COMPARISON OF THE READING PERFORMANCE TEST IN ENGLISH AND THE WRITING PERFORMANCE TEST IN ENGLISH}

Figure 7: Comparison of results of the Reading Performance Test in English and the Writing Performance Test in English

Figure 7 presents the comparison of the combined results of the Reading Performance Test in English and the Writing Performance Test in English. 


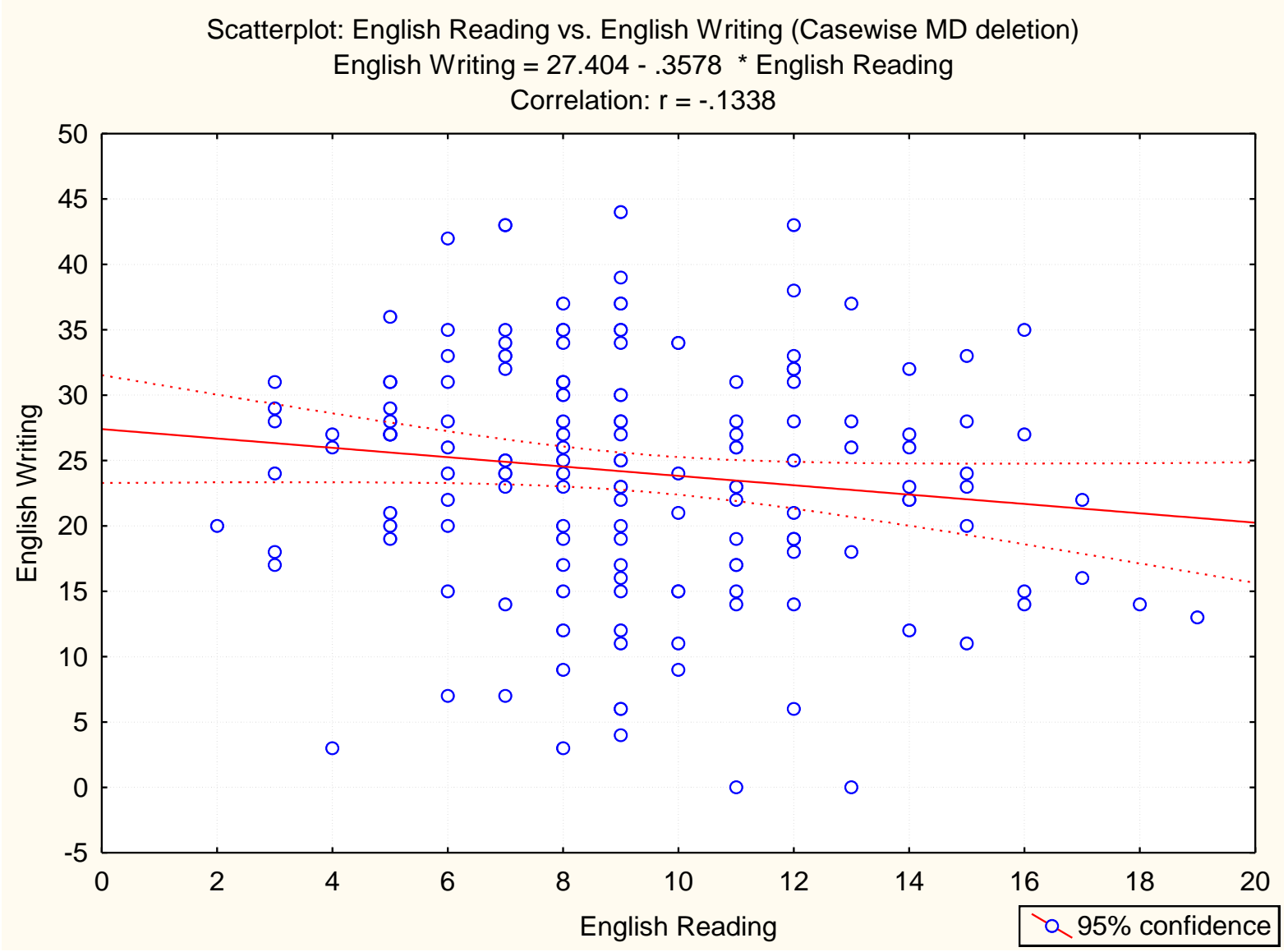

Figure 7 shows a weak negative correlation between the Reading Performance in English and the Writing Performance in English as evidenced by the correlation coefficient of $r=-0.1338$, and a coefficient of determination $\mathrm{r}^{2}=(-0.1338)^{2}=0.0179$. It shows that only $2 \%$ of the variability in Writing results is explained by Reading results. Thus, reading performance only accounts for $2 \%$ of writing performance.

When a regression line was fitted to the data with Writing as the dependent, the maximum expected mark in Writing was found to be 27 out of 50, regardless of the reading skills. Since these variables have a negative relationship, it can be noted that, for every increase of 1 mark in reading, writing decreases by 0.38 . Thus, reading impacts somewhat negatively on learners' performance in writing.

There was no statistical difference between the Reading Performance Test in English and the Writing Performance Test in English, $\mathrm{p}=.00328$. The results for both the Reading and the Writing Performance Tests in English are very low and indicate learners' poor ability to cope with reading and writing performance in English as required by the demands of the LoLT in the senior primary phase.

\section{DISCUSSION AND CONCLUSIONS}

The Reading Performance Test in English and the Writing Performance Test in English were assessed out of the possible maximum scores of 40 and 50 respectively. This discussion interrogates the results based on the four components of the respective tests: reading 
comprehension; and grammar (Tables 1 and 2); and spelling and syntax; and sentence writing and creative writing (Tables 3 and 4).

According to the language policy adopted by the three schools that were studied, Grade 4 marks a sudden transfer to English as the LoLT for the entire curriculum, which concurrently broadens into learning (content) areas, each with its own technical vocabulary, concepts and discourse. A disparity between Grade 4 learners' L2 proficiency and the proficiency required of them to master new academic content through English as LoLT has been well documented (MacDonald, 1990; Heugh, 2002; Pretorius \& Mampuru, 2007). If language learning conditions are optimal, as envisaged by language policy aims, learners by Grade 7 could be expected to have acquired surface elements of language (basic vocabulary, comprehension and grammar) which would allow them to express themselves in undemanding, context-embedded situations (Cummins, 2000). In addition, it could be expected that they would be demonstrating Krashen's (1982) level of intermediate fluency, in which L2 learners demonstrate some academic language proficiency which includes good comprehension and the ability to analyse, support and evaluate subject matter. However, Grade 7 learners would have had insufficient time (five to seven years) to reach Krashen's (1982) final level of advanced fluency in which they can use subject-specific technical vocabulary with ease and demonstrate reading and writing skills in context-reduced situations necessary for overall school success. In the light of this, the learner performance in English reading and writing demonstrated in this study, which ranged from very poor to moderate, strongly suggests that the learners have not yet reached a level of English proficiency that will enable them to cope with the reading and writing demands of the Grade 7 curriculum.

Furthermore, the literature indicates a complementary relationship between reading and writing abilities. Common cognitive processes and text structural components underlying reading and writing abilities imply that development in one skill enhances capabilities in the other. However, this study did not demonstrate this relationship. No significant correlation was found between English reading and English writing skills; in fact, the results (Figures 3 and 6) show a huge difference between scores for the different components and the combined components. This can possibly be explained by Cummins' (2000) distinction between 'context-embedded' and 'context-reduced' communication. In 'context-embedded' communication, learners can actively negotiate meaning and language is supported by a wide range of paralinguistic or situational cues. This comprises a cognitively undemanding situation where a person has mastery of language skills sufficient to enable easy communication. During 'context-reduced' communication, very few overt cues convey meaning. The communication relies primarily on linguistic cues to meaning and may even involve suspending knowledge of the real world in order to manipulate the logic of the message. With regard to this study, the reading component (cf. Tables 1 and 2) was relatively context reduced. The reading passages were accompanied by illustrations; however, these offered the reader few clues as to the correct answers to the questions. The illustrations merely indicated the topics of the passages. Specific items in the grammar component required idiomatic understanding, inferences regarding atmosphere and the extension of the meaning of the text, activities which lie towards the cognitively demanding pole of Cummins' model. The writing component (Tables 2 and 3) were also accompanied by illustrations, but in this case the latter were designed to act as stimuli for writing tasks. Interestingly, the learners did not perform as well with formal writing tasks that required denotative understanding of words, correct spelling and syntax as they did when they were allowed the relative freedom of writing expressively. Thus, it can be said that writing activities lay closer to the pole of context-embedded and cognitively undemanding situations. 
In this context, English reading and writing proficiency necessary to cope with the curriculum implies that a L2 learner should be able to comprehend a range of texts and execute writing tasks required in all learning areas. When Grade 7 learners have reached at least an intermediate level of language proficiency, they will be able to concentrate not only on the meaning and structure of the language, but also on subject knowledge and its demands. To do this, learners clearly must be supported linguistically in a language enriched classrooms; however, in most South African schools, conditions are not optimal (Nel \& Swanepoel, 2009). This begs the question as to whether the use of English as LoLT is adding value to children's education.

\section{REFERENCES}

ALEXANDER, N. 2002. Linguistic rights, language planning and democracy in postapartheid South Africa. In Baker, SJ. (Ed), Language policy: Lessons from global models. Monterey: Monterey Institute of International Studies.

ALEXANDER, N. 2005. Key issues in language policy for southern Africa. In Trewby, R \& $\mathrm{S}$ Fitchat (Eds), Language and development in southern Africa: Making the right choices. Windhoek: Gamsberg Macmillan.

BERNARD, I \& S REINECKE 1992. English Writing Performance Test. Intermediate Level. Pretoria: Human Sciences Research Council.

BROCK-UTNE, B \& HB HOLMARSDOTTIR. 2004. Language policies and practices in Tanzania and South Africa: problems and challenges. International Journal of Educational Development, 24(1):67-83.

CAMPBELL, P. 1995. The interdependence of reading, writing and critical thinking. Opinion paper, Eric Digest ED395274 [Online]. Available: www.eric.ed.gov [2009, 25 May].

CHAMBERLAIN, JC \& S REINECKE. 1992. Manual: Proficiency Test English second language intermediate level. Pretoria: Human Sciences Research Council.

CHRISTIAN, D, G SPANOS, J CRANDALL, C. SIMICH-DUDGEON \& K WILLETS. 1995. Combining language and content for second language students. In Garcia, O \& C Baker (Eds), Policy and practice in bilingual instruction. Clevedon: Multilingual Matters.

COLLIER, VP. 1995. Acquiring a second language for school. National Clearinghouse for Bilingual Education, 1(4).

CONNOR, U. 1996. Contrastive rhetoric: Cross-cultural aspects of second language writing. Cambridge: Cambridge University Press.

CRANDALL, J. 1994. Content-centered language learning. Eric Digest ED 367142. Washington, DC: Centre for Applied Linguistics.

CUMMINS, J. 2000. Language, power and pedagogy: Bilingual children in the crossfire. Clevedon: Multilingual Matters.

DANIELS, H, S ZEMELMAN. \& V STEINEKE. 2007. Content-area writing. New York: Heinemann.

DEPARTMENT OF EDUCATION (DoE). 2002. The Revised National Curriculum Statement. Pretoria: Government Printers.

HALL, LA. 2005. Teachers and content area reading: Attitudes, beliefs and change. Teaching and Teacher Education, 21(4):403-414. 
HARKLAU, L. 2002. The role of writing in classroom second language acquisition. Journal of second language acquisition, 11(4):329-350.

HEUGH, K. 1995. From unequal education to the real thing. In Heugh, K, A Siegruhn \& P Plüddemann. Multilingual education for South Africa. Pretoria: DALRO.

HEUGH, K. 2000. The case against bilingual and multilingual education in South Africa. Occasional Paper No. 6. Cape Town: PRAESA.

HUMAN SCIENCES RESEARCH COUNCIL (HSRC). 2004. Annual report: Emerging voices. A report on Education in South African communities. Pretoria: HSRC Press.

HYLAND, K. 2007. Genre pedagogy: Language, literacy and L2 writing instruction. Journal of Second Language Writing, 16(3):148-164.

INTERNATIONAL ASSOCIATION FOR THE EVALUATION OF EDUCATIONAL ACHIEVEMENT 2006. PIRLS 2006 International Report [Online]. Available: http://timss.bc.edu/PDF/p06 international report.pdf [2009, 20 June].

KAPLAN, RB. 1966. Cultural thought patterns in inter-cultural education. Language learning, 16:1-20.

KANG, H. 1992. The effects of culture specific knowledge upon ESL reading comprehension. School of Education Review, 4,93-105.

KAUFFMAN, D \& J CRANDALL. 2005. Content-based instruction in elementary and secondary school settings. Alexandria, VA: TESOL.

KRASHEN, S. 1982. Principles and practice in second language acquisition. New York: Pergamon Press.

KRASHEN, S. 1990. We learn to write by reading, but writing can make you smarter. In Atlatis, E (Ed), Georgetown University Round Table on Languages and Linguistics: Linguistics, language teaching and language acquisition: the interdependence of theory, practice and research. Washington, DC: Georgetown University Press.

McCLELLAN, S \& ME FIELDS. 2004. Using African American children's literature to support literacy development. Young Children, 59(3):50-54.

MACDONALD, CA. 1990. Crossing the threshold into standard three in black education: the consolidated main report of the Threshold Project. Pretoria: Human Sciences Research Council.

MACDONALD, CA. 2006. The properties of mediated action in three different literacy contexts. Theory and Psychology, 16(1):51-80.

MARTIN, T \& B LEATHER. 1994. Readers and text in the primary years. Buckingham: The Open University Press.

MOLOI, M. \& J STRAUSS. 2005. The SACMEQ11 Project in South Africa: A study of the conditions of schooling and quality of education. Harare: SACMEQ.

NEL, N \& E SWANEPOEL. 2009. The influence of ESL student teachers' English proficiency on learners in South African schools. Unpublished paper delivered at Ninth international conference on diversity in nations, societies and organisations, held from July 16-19 July 2009, in Riga, Latvia.

NEW SOUTH WALES DEPARTMENT OF EDUCATION AND TRAINING. 1999. Focus on Literacy: Writing. New South Wales: Curriculum Support Directorate. 
PASTOWSKY, P. 2008. The politics of English in South Africa. Unpublished scholarly paper presented at the Advanced Seminar: The politics of English as a global language, Humboldt University of Berlin, Berlin.

PAWAN, F. 2008. Content-area teachers and scaffolded instruction for English second language users. Teaching and teacher education, 24(6):1450-1462.

PRESSLEY, M, L MOHAN, LM RAPHAEL \& L FINEGRET. 2007. How Does Bennett Woods Elementary School Produce Such High Reading and Writing Achievement? Journal of Educational Psychology, 99(2):221-240.

PRETORIUS, EJ \& DM MAMPURU. 2007. Playing football without a ball: language, reading and academic performance in a high-poverty school. Journal of Research in Reading, 30(1):38-58.

REPUBLIC OF SOUTH AFRICA (RSA) 2008. South Africa yearbook 2007/08 (1): the land and its people. Pretoria: Government Communication and Information System (GCIS).

RODSETH, JV. 1999. Innovative second language acquisition in Southern Africa. In Tucker, GR \& D Corson. Second language education. New York: Kluwer Academic.

ROUX, WA. (1997). Manual: Writing Performance Test in English. Advanced level. Pretoria: Human Sciences Research Council.

SCHLEPPEGRELL, M \& LC DE OLIVIERA. 2006. An integrated language and content approach for history teachers. Journal of English for Academic Purposes, 5(4):254-268.

STAKE, RE. 2005. Qualitative case studies. In Denzin, NK \& YS Lincoln. The Sage handbook of qualitative research ( $2^{\text {nd }}$ edition). Thousand Oaks: Sage.

UYSAI, HH. 2007. Tracing the culture behind writing: Rhetorical patterns and bidirectional transfer in L1 and L2 essays of Turkish writers in relation to educational context. Journal of Second language writing, 17(3):183-2007.

VIRGINIAN DEPARTMENT OF EDUCATION. 2006. English: Strategies for Teaching Limited English Proficient students [Online]. Available: http://www.doe.virginia.gov. [2009, 1 June]

\section{BIOGRAPHICAL NOTE}

Tintswalo Vivian Manyike is senior lecturer in the Department of Educational Studies at the University of South Africa, Her research interests include multicultural/bilingual education, teaching English as a second language and language policy in education. Email: manyitv@unisa.ac.za

Eleanor Lemmer is professor in the field of Comparative Education in the Department of Further Teacher Education at the University of South Africa. Her research interests include language policy in multicultural schools in South Africa and parent involvement. Email: lemmeem@unisa.ac.za 